\title{
Association between Anthropometric Measures of Obesity, Metabolic Disturbances and Polymorphism G-308A of the Tumor Necrosis Factor-Alpha Gene in Children
}

\author{
B. Pyrzak ${ }^{1}$, A. Wisniewska ${ }^{1}$, K. Popko ${ }^{2}$, U. Demkow ${ }^{2}$, A. M. Kucharska ${ }^{1}$ \\ ${ }^{1}$ Department of Pediatrics and Endocrinology, Warsaw Medical University, Warsaw, Poland; \\ ${ }^{2}$ Department of Laboratory Diagnostics and Clinical Immunology of the Developmental Age, Warsaw Medical University, Warsaw, Poland
}

\begin{abstract}
Introduction: TNF- $\alpha$ is one of the most important factors in the development and course of inflammation. It is suggested that polymorphism located in the 5 'regulatory region of the TNF- $\alpha$ gene at position 308 (guanine $[\mathrm{G}] \rightarrow$ adenine $[\mathrm{A}]$ ) may increase the expression of this cytokine in fat tissue and influence the fat mass and insulin resistance.

Objective: To investigate whether the G-308A polymorphism of the TNF- $\alpha$ gene may influence obesity, insulin resistance, fasting plasma lipids, serum leptin levels, and the incidence of metabolic syndrome.

Material and methods: The obese group included 124 children with simple obesity ( 72 girls and 52 boys) aged 10-18 (mean age 15 years) with SDS of BMI $\geq 2.0$. A control group consisted of 56 healthy nonobese children (36 girls and 20 boys) aged 11-18 (mean age 14 years) with SDS of BMI <1.0. Polymorphism identification was performed in total genomic DNA, using PCR-RFLP method.

Results: Carriers of $\mathrm{A}(\mathrm{AG}+\mathrm{AA})$ allele among the obese children were significantly more frequent than in the control group $\left(\mathrm{OR}=2.29,95 \%\right.$ CI 1.2-4.4, $\chi^{2}=$ 6.24, $\mathrm{P}<0.05)$. Carriers of $\mathrm{A}$ alleles showed a higher concentrations of fasting glucose $(81.3 \pm 10.5$ vs. 77.4 $\pm 10.3 \mathrm{mg} / \mathrm{dl} ; \mathrm{P}<0.05)$, but lower values of fasting insulin $(15.1 \pm 7.3$ vs. $19.0 \pm 9.5 \mu \mathrm{IU} / \mathrm{ml} ; \mathrm{P}<0.05)$, lower values of HOMA index $(3.0 \pm 1.5$ vs. $3.7 \pm 2.0 ; \mathrm{P}$ $<0.05)$. In the group of boys, carriers of $\mathrm{A}$ alleles showed a tendency for lower concentrations of HDL (43.8 \pm 12.6 vs. $48.3 \pm 11.8 \mathrm{mg} / \mathrm{dl} ; \mathrm{P}<0.05)$. Blood pressure and leptin level did not differ between the obese children with gene polymorphism and those of wild homozygous. The incidence of the full metabolic syndrome (MetS) in the children, according to the IDF definition, was $33 \%$. The presence of the MetS in children with wild homozygous GG and carriers of A allele of TNF- $\alpha$ polymorphism gene did not show statistical differences $\left(\mathrm{OR}=1.38 ; 95 \%\right.$ CI $0.6-3.1, \chi^{2}=$ $0.58)$.

Conclusions: 1/ Polymorphism G-308A of the TNF- $\alpha$ gene is more common in children with obesity; and 2/ Polymorphism G-308A of the TNF- $\alpha$ gene does not seem to be associated with the grade of obesity, insulin resistance, lipid profile, leptin levels, and the incidence of metabolic syndrome in obese children.
\end{abstract}

Key words: TNF- $\alpha$, G-308A, polymorphism, pediatric obesity, metabolic syndrome

\section{INTRODUCTION}

The increasing incidence and severity of obesity in children is a growing health concern [1]. Obesity is directly translated to the increase in the prevalence of chronic morbidities such as insulin resistance, metabolic syndrome, dyslipidemia, systemic hypertension, atherosclerosis, sleep apnea, fatty liver/steatohepatitis, depression and decreased quality of life in both adults and children [2-5]. In the pathogenesis of obesity, apart from environmental factors, a key role is played by genetic predisposition [6].

Adipose tissue is an important endocrine organ with active participation in several metabolic processes, including production of pro- and anti-inflammatory cytokines that play a role in the development of obesity-related diseases, like diabetes and hypertension. Tumor necrosis factor-alpha $(\mathrm{TNF}-\alpha)$ is a multifunctional cytokine that can regulate many cellular and biological processes such as immune cell function, apoptosis and energy homeostasis, and is considered as a candidate gene for obesity [7].

In both rodent and human models of the metabolic syndrome, macrophages chemoattracted with monocyte chemoattractant protein-1 (MCP-1) have been found to infiltrate adipose tissues and produce TNF- $\alpha$ [8]. This cytokine induces insulin resistance which may be a cause of metabolic syndrome [9]. It is proved that polymorphisms located in cytokine genes may affect the level of protein expression. The level of TNF- $\alpha$ depends significantly on the presence of polymorphism G-308A in the structure of TNF- $\alpha$ gene. The presence of A allele provokes double increase of TNF- $\alpha$ gene expression and leads to higher TNF- $\alpha$ production $[10,11]$.

Previously we have shown the presence of the relationship between polymorphism G-308A located in promoter region of TNF- $\alpha$ gene and the development of obesity and sleep apnea in adults [12]. Other studies have documented that adult individuals who carried the 308A TNF- $\alpha$ gene variant are at risk for conversion from impaired glucose tolerance to type 2 diabetes $[13,14]$. However, many other studies have reported no correlation between this TNF- $\alpha$ mutation 
and insulin resistance or any other metabolic abnormality of the insulin resistance syndrome $[15,16]$. Although a number of studies have examined the association between the G-308A variant, obesity, and components of the metabolic syndrome in adults [17, 18], to our knowledge, no such study has been carried out in pediatric population. On the other hand, it seems to be important if deleterious effects of genetic markers of inflammatory responses are already present in obese children and adolescents. The aim of the present study was to evaluate the influence of the $G$ $308 \mathrm{~A}$ TNF- $\alpha$ promoter gene variant on the occurrence of phenotypes associated with the metabolic syndrome in overweight and obese children.

\section{Material And Methods}

The study was approved by the Research and Ethics Committee of Warsaw Medical University in Warsaw, Poland. The examined group included 124 obese children and adolescents with simple obesity (72 girls and 52 boys) aged 10-18 (mean age 14.6 years), recruited from an outpatient endocrinology clinic of Children's Hospital at Warsaw Medical University. Body mass in$\operatorname{dex}\left(\mathrm{BMI} ; \mathrm{kg} / \mathrm{m}^{2}\right.$ ) of all obese subjects was $>95^{\text {th }}$ percentile for age and sex reference values. The control group consisted of 56 healthy normal weight (BMI $<85^{\text {th }}$ percentile for age and sex reference values) children (36 girls and 20 boys) aged 11-18 (mean age 14.0 years). All included children were free from any allergic disease, immune, and hematological disorders There were no significant differences in age and sex among obese and non-obese children. A complete history was obtained, and physical examination was carried out on all the participants. Height $(\mathrm{cm})$, weight $(\mathrm{kg})$, and blood pressure $(\mathrm{mmHg})$ were measured using a standardized equipment. BMI z-score adjusted for age and sex was calculated using normative data. Obesity was defined as a BMI z-score of more than +2 . Waist circumference $(\mathrm{cm})$ was measured and referred to percentile charts. Hip circumference $(\mathrm{cm})$, waist-to-hip ratio (WHR), and the sum of thickness of 3 and 10 skin and fat folds ( $\mathrm{mm})$ also were measured. Percentage of fat tissue content measured in skin and fat folds on the arm and below the shoulder blade was calculated using Slaughter's equation [19]. All children in the control group were at 25 percentile or less of the obesity measures. Hypertension was defined as a value of systolic and/or diastolic blood pressure $\geq$ 95 $5^{\text {th }}$ percentile for sex and age. Prehypertension was defined as a value of systolic and/or diastolic blood pressure from the $90^{\text {th }}$ to $95^{\text {th }}$ percentile.

\section{Biochemical Tests}

Oral glucose tolerance test (OGTT) with measurements of glucose and insulin levels at 0, 30, 60, 90, 120 min after 10-12 hour fast was performed with the use of a standard dose of glucose $(1.75 \mathrm{~g} / \mathrm{kg}$, max. 75 $\mathrm{g})$ in the group of obese children. Insulin concentrations were measured by RIA (Radio-Immuno-Assay) and the plasma glucose level was measured using drychemistry method. Abnormal fasting glycemia (IFG) was recognized when fasting plasma glucose concen- tration was $\geq 100(\mathrm{mg} / \mathrm{dl})$, impaired glucose tolerance (IGT) when glucose concentration $2 \mathrm{~h}$ post-OGTT was from 140 to $200(\mathrm{mg} / \mathrm{dl})$, and diabetes (DM) when fasting plasma glucose concentration was twice above $126(\mathrm{mg} / \mathrm{dl})$ and plasma glucose $2 \mathrm{~h}$ after the 75 $\mathrm{g}$ glucose load was above 200 (mg/dl). Hyperinsulinemia was recognized when fasting levels of insulin were greater than $15(\mu \mathrm{IU} / \mathrm{ml})$ or insulin post-OGT'T peak levels were more than $150(\mu \mathrm{IU} / \mathrm{ml})$, and/or more than $75(\mu \mathrm{IU} / \mathrm{ml}) 2 \mathrm{~h}$ post-OGT'T. Insulin resistance was estimated using fasting plasma insulin homeostasis model assessment HOMA (Gluk0min (mmol/l) $\mathrm{x}$ Ins0min $(\mu \mathrm{IU} / \mathrm{ml}) / 22.5)$. The oral glucose insulin sensitivity OGIS90 index was calculated from 2 h OGTT.

Plasma total cholesterol (T-C) and triglycerides (TG) were determined enzymatically on a Hitachi 912 analyzer (Roche Diagnostics). HDL-cholesterol (HDLC) was measured using a homogenous method with polyethylene glycol-modified enzymes and alpha-cyclodextrin. LDL-cholesterol (LDL-C) was calculated by the Friedewald equation. The upper limits for total cholesterol (T-C), triglycerides (TG), and LDL-C were set at $>200,130$, and $150 \mathrm{mg} / \mathrm{dl}$, respectively; and the lower limits for high-density lipoprotein cholesterol (HDL-C) were set at $<45$ and $50 \mathrm{mg} / \mathrm{dl}$ for boys and girls, respectively. Leptin concentration measured by RIA (Radio-Immuno-Assay) was referred to the reference value of $15-20 \mathrm{ng} / \mathrm{dl}$. The International Diabetes Federation (IDF) criteria for children and adolescence were used to evaluate the incidence of the metabolic syndrome (MetS) [20].

\section{Genetic Tests}

Genomic DNA was isolated using a Genomic Midi AX isolation kit with ion-exchange membranes (A \& A Biotechnology, Gdynia, Poland). Genotyping was done using polymerase chain reaction-restriction fragment length polymorphism analyses. Genomic DNA was amplified with specific flanking primers for TNF$\alpha$ G/A. The primers used in the PCR were: forward 5'AGGCAATAGGT'T'T'TGAGGGCCAT 3', and reverse 5'TCCTCCCTGCTCCGAT'TCCG 3'.

Amplification was carried out in a $50 \mu \mathrm{l}$ volume, containing $1.5 \mathrm{mmol} / 1 \mathrm{MgCl}_{2}, 0.2 \mathrm{mmol} / 1 \mathrm{dNTP}, 1 \mathrm{U}$ polymerase TaqGold (Applied Biosystems), 0.2 mmol/1 each primer (DNA-Gdansk). Thirty six cycles were conducted in the thermocycler, Mastercycler personal, under the following conditions: initial denaturation at $94^{\circ} \mathrm{C}$ for $3 \mathrm{~min}$, denaturation at $94^{\circ} \mathrm{C}$ for $60 \mathrm{~s}$, annealing at $60^{\circ} \mathrm{C}$ for $60 \mathrm{~s}$, extension at $72^{\circ} \mathrm{C}$ for $60 \mathrm{~s}$, and final extension at $72^{\circ} \mathrm{C}$ for $5 \mathrm{~min}$. The amplified PCR product was digested with the addition of $5 \mathrm{U}$ enzymes NcoI. The digested samples were separated by electrophoresis through a $2 \%$ agarose gel and visualized following ethidium bromide staining. The identified genotypes were recognized according to the presence or absence of the enzyme restriction sites.

\section{STATISTICAL ANALYSIS}

The results are presented as means $\pm S D$, minimum and maximum. Normality of data distribution was assessed with a Shapiro-Wilk test. A t-test for indepen- 
dent and non-independent samples was used to determine the statistical difference between genders in mean values for each group. Logistic regression was used to investigate the relationship between the obesity measures, syndrome features, and the examined polymorphisms. The proportional odds model was also used to obtain ORs for the association of each obesity measure with the every genotype. $\mathrm{Chi}^{2}$ test was used to investigate the distribution of genetic polymorphism between the case and control groups and to find an association between the assessed categorical variables. The results were processed statistically using Statgraphics 4.0 plus and STATISTICA 6.0 software. Statistical significance was accepted at $\mathrm{P}<0.05$. The Hardy-Weinberg equilibrium test was applied to evaluate genotype frequencies.

\section{RESUlts}

Analysis of anthropometric and metabolic parameters was performed only in the group of obese children. Genetic analysis was performed in both: cases and controls. Anthropometric characteristics of the obese children and adolescent is presented in Table 1. SDS waist circumference, considered to be one of the most important elements of the metabolic syndrome, was higher than the reference values across the whole study group. All obese children presented with waist circumference $>90$ percentile. Metabolic characteristics of the study group are presented in Table 2 . Two of the obese children fulfilled the criteria for diabetes type 2 . The incidence of the full MetS (central obesity plus 2 or more abnormalities) was present in $33 \%$ of

Table 1. Anthropometric characteristics of obese children.

\begin{tabular}{|c|c|c|c|}
\hline \multirow[t]{2}{*}{ Anthropometric parameters } & \multirow[t]{2}{*}{ Mean \pm SD } & \multicolumn{2}{|c|}{$\%$ children with parameters } \\
\hline & & $\geq 2 \mathrm{SD}<3 \mathrm{SD}$ & $\geq 3 \mathrm{SD}$ \\
\hline Age (yr) & $14.6 \pm 1.7$ & - & - \\
\hline Height (m) & $167.7 \pm 9.3$ & 19.7 & 0.8 \\
\hline Body weight $(\mathrm{kg})$ & $91.4 \pm 17.0$ & 39.8 & 60.3 \\
\hline Body mass index $\left(\mathrm{kg} / \mathrm{m}^{2}\right)$ & $32.2 \pm 4.0$ & 17.6 & 82.4 \\
\hline SDS body mass index (z-score) & $4.4 \pm 1.5$ & - & - \\
\hline Waist circumference $(\mathrm{cm})$ & $98.0 \pm 10.8$ & $\begin{array}{c}100 \% \\
>\mathbf{9 0} \text { percentile } \\
\text { boys }-100 \% \\
\text { girls }-100 \%\end{array}$ & $\begin{array}{c}82.5 \% \\
>\mathbf{9 5} \text { percentile } \\
\text { boys }-90 \% \\
\text { girls }-75 \%\end{array}$ \\
\hline SDS waist circumference & $3.7 \pm 1.2$ & - & - \\
\hline Hip circumference $(\mathrm{cm})$ & $112.4 \pm 13.3$ & - & - \\
\hline Waist to hip ratio - WHR & $0.86 \pm 0.07$ & - & - \\
\hline Sum of 3 skinfolds (mm) & $72.8 \pm 11.5$ & - & - \\
\hline Sum of 10 skinfolds (mm) & $172.0 \pm 26.8$ & - & - \\
\hline$\%$ body fat -Slaughter equation & $35.3 \pm 5.3$ & - & - \\
\hline
\end{tabular}

Table 2. Metabolic parameters in the group of the obese children.

\begin{tabular}{|c|c|c|c|}
\hline $\begin{array}{l}\text { Metabolic parameters and } \\
\text { blood pressure }\end{array}$ & Mean \pm SD & Cut-off point & $\begin{array}{l}\% \text { children } \\
\text { above cut-off }\end{array}$ \\
\hline $\mathrm{T}-\mathrm{C}(\mathrm{mg} / \mathrm{dl})$ & $171.9 \pm 34.1$ & $\geq 200$ & 20 \\
\hline \multirow[t]{2}{*}{$\mathrm{HDL}-\mathrm{C}(\mathrm{mg} / \mathrm{dl})$} & $45.6 \pm 12.2$ & $\leq 45$ (boys) & 60 \\
\hline & & $\leq 50$ (girls) & 65 \\
\hline LDL-C (mg/dl) & $101.2 \pm 27.7$ & $\geq 150$ & 5 \\
\hline $\mathrm{TG}(\mathrm{mg} / \mathrm{dl})$ & $134.2 \pm 57.9$ & $\geq 130$ & 44 \\
\hline Glucose 0 min OGTT (mg/dl) & $79.2 \pm 10.1$ & $\geq 100$ & 2 \\
\hline Glucose $120 \mathrm{~min}$ post-OGTT $(\mathrm{mg} / \mathrm{dl})$ & $106.6 \pm 26.0$ & $\geq 140<200$ & 7 \\
\hline Insulin 0 min OGTT $(\mu \mathrm{IU} / \mathrm{ml})$ & $17.5 \pm 8.7$ & $\geq 15$ & 55 \\
\hline Insulin 120 min post-OGTT & $80.9 \pm 68.7$ & $\geq 75$ & 36 \\
\hline \multirow[t]{2}{*}{ Leptin $(\mathrm{ng} / \mathrm{ml})$} & $27.2 \pm 13.2$ & $\geq 20$ & 75 girls \\
\hline & & & 80 boys \\
\hline HOMA & $3.4 \pm 1.7$ & $>3.0$ & 80 \\
\hline OGIS $_{90}$ & $427.9 \pm 84.7$ & - & - \\
\hline \multirow[t]{2}{*}{ Systolic blood pressure (mmHg) } & $124.8 \pm 10.2$ & $>90$ percentile & 50 \\
\hline & & $>95$ percentile & 45 \\
\hline
\end{tabular}




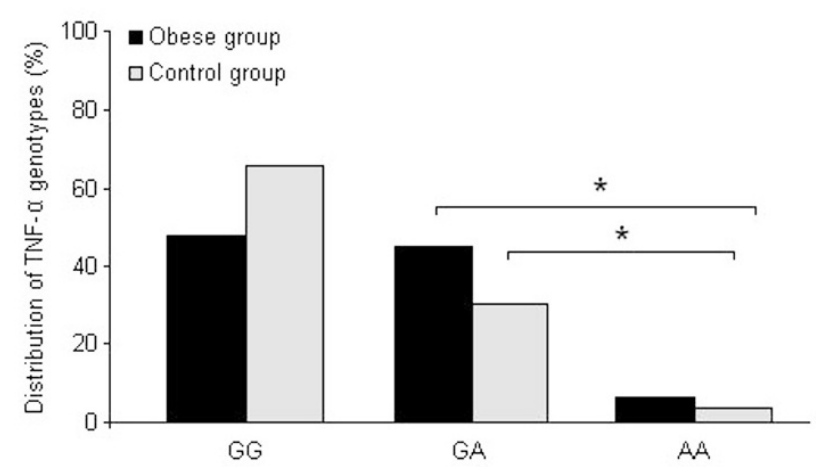

Fig 1. Distribution of TNF- $\alpha$ genotypes in obese and healthy children.

obese children. The frequency distribution analysis of polymorphism TNF- $\alpha$ G-308A in obese and nonobese children is presented in Fig. 1.

The frequency of alleles $\mathrm{G}$ and $\mathrm{A}$ in both case and control groups were in HW equilibrium. Carriers of $\mathrm{A}$ allele $(\mathrm{AG}+\mathrm{AA})$ in the obese were more frequent than in the control group OR $=2.29(95 \%$ CI 1.2-4.4); the difference being significant $\mathrm{Chi}^{2}=6.24(1 \mathrm{df}), \mathrm{P}<0.05$. Homozygous carriers of AA genotype in the obese were more frequent than in the control group $\mathrm{OR}=$ 1.88 (95\% CI $=0.4-9.2)$; but the difference here was insignificant $\mathrm{Chi}^{2}=0.67(1 \mathrm{df})$.

The HDL-C level was lower in the carriers of A alleles (GA+AA) compared with GG homozygotes (43.8 \pm 12.6 vs. $48.3 \pm 11.8 ; \mathrm{P}<0.05)$. The carriers of $\mathrm{A}$ alleles also showed a stronger tendency for higher values of fasting glucose concentrations $(81.3 \pm 10.6 \mathrm{vs}$. $77.4 \pm 10.3$; $\mathrm{P}<0.05$ ), but lower values of fasting insulin $(15.1 \pm 7.3$ vs. $19.0 \pm 9.5 ; \mathrm{P}<0.05)$, and lower values of HOMA index $(3.0 \pm 1.5$ vs. $3.7 \pm 2.0 ; \mathrm{P}<0.05)$. In the group of boys carrying A alleles, a lower level of HDL (43.8 \pm 12.6 vs. $48.3 \pm 11.8$; $\mathrm{P}<0.05)$ was observed compared with the boys with GG genotype. The systolic blood pressure and leptin concentration did not differ between the obese children with gene polymorphism and wild homozygous. Only was there a tendency for lower values of TG and leptin in the carriers of $\mathrm{A}$ alleles. The presence of the metabolic syndrome in children with wild homozygous GG and carriers of A allele of TNF- $\alpha$ polymorphism gene did not show statistical differences $(\mathrm{OR}=1.38 ; 95 \% \mathrm{CI}$ 0.6-3.1 $\mathrm{Chi}^{2}=0.58 \mathrm{NS}$ ).

\section{DISCUSSION}

TNF- $\alpha$ has been implicated in the pathogenesis of insulin resistance and obesity. In humans, adipose tissue TNF- $\alpha$ expression correlated with BMI, percentage of body fat, and hyperinsulinemia, whereas weight loss decreased TNF- $\alpha$ levels [21]. The increased expression of TNF- $\alpha$ in adipose tissue has been shown to induce insulin resistance, and polymorphism at position -308 in the promoter region of $\mathrm{TNF}^{-\alpha} \boldsymbol{\alpha}$ has been shown to increase transcription of the gene in adipocytes [22].

The genetic studies on the possible role of TNF- $\alpha$ in the etiopathogenesis of insulin-resistance and/or its associated metabolic abnormalities shown conflicting results. Linkage has been detected between a marker near TNF- $\alpha$ and obesity in Pima Indians [23] and a another study on a small population (38 subjects) has confirmed this result showing a rise in BMI and fasting plasma insulin in subjects carrying the G-308A TNF- $\alpha$ polymorphism [24]. Results of some other studies do not find correlations with either metabolic (fasting insulin, fasting glucose, $\mathrm{HOMA}_{\mathrm{IR}}$ ) or anthropometric parameters (body fat distribution, FFM, TBW) $[25,26]$. The large cohort studies in Chinese, Caucasians, and American blacks also failed to show a correlation between G-308A polymorphism and insulin resistance or obesity [27, 28], suggesting only a marginal role of TNF- $\alpha$ in the pathogenesis of these metabolic conditions.

The results of the present study may contribute to the resolution of controversy concerning the association between the $G-308 \mathrm{~A}$ TNF- $\alpha$ polymorphism and components of the metabolic syndrome. We found that the G-308A allele may confer a risk for obesity in children. The frequency of allele $\mathrm{A}$ in the obese children was significantly higher than in the non-obese ones. This effect is even more pronounced than that observed in obese adults [12]. This may indicate that genetically-based TNF- $\alpha$ expression plays an important role in obesity development acting earlier in life, but its action wanes with time, or some other pathogenic factors may play more important role in obesity development later in life. We may also hypothesize that genetic factors plays a stronger role in childhood being overridden by other (environmental) factors later on. The function of this polymorphism is unfortunately still unclear. It is located in the DNA sequence responsible for the binding of AP-2 transcription factor. This polymorphic variant has been shown to affect the promoter region of the TNF- $\alpha$, gene leading to a higher rate of transcription compared to G-308A allele. Even though our analysis found an association between TNF- $\alpha$ genotypes and BMI, there has been heterogeneity among studies. A possible explanation for it is gender, age, or ethnical distribution, as those differences may be important confounding factors. For example, the prevalence of $\mathrm{A}$ allele carriers seems to be as high as $45 \%$ among whites, but in the Asian population, the frequency of the G-308A TNF- $\alpha$ allele is very low. In the present study we also attempted to find a relationship between TNF- $\alpha$ genotype and the presence of the components of metabolic syndrome.

The term "metabolic syndrome", a known risk factor for cardiovascular disease in adults, clusters insulin resistance, dyslipidemia, hypertension, and obesity. Elevation of fasting insulin levels and increased BMI during childhood emerged as the strongest predictors of the metabolic syndrome in adulthood [29]. Moreover, insulin resistance in childhood is associated with increased risk for later cardiovascular morbidity and mortality [30]. In the present study we were unable to find a relationship between TNF- $\alpha$ polymorphism and elevated blood pressure in children. It is noteworthy that the pathogenesis of both obesity and hypertension is complex, probably involving several genes and environmental factors. However, genetic analysis suggests that some of the genes that confer susceptibility to obesity may also contribute to the develop- 
ment of obesity-associated hypertension; one such gene may be TNF- $\alpha$ [31]. As fasting insulin, hypertension, and obesity are strongly related phenotypes, it is difficult to define which the cause of which is. Many studies demonstrate that white A allele carriers have an excess risk for obesity and higher values of SABP, as well as higher plasma insulin levels. However, we were unable to confirm this observation. Some author state that obesity and insulin resistance may either be related variables or have common causes acting later in life; in which TNF- $\alpha$ plays an important role. More studies are necessary to investigate whether the TNF$\alpha$ exerts its influence on systolic arterial blood pressure earlier and independently of its effect on insulin resistance and body weight. It may be speculated that high levels of plasma TNF- $\alpha$ could be associated with vascular vasoconstriction. This hypothesis is consistent with the fact that TNF- $\alpha$ induces the synthesis of endothelin-1, a potent vasoconstrictor [32]. In addition, it has been demonstrated that patients with uncomplicated mild essential hypertension show elevated plasma intercellular adhesion molecule-1 and TNF$\alpha$ concentrations [33], which suggests that the metabolic syndrome is a low-grade, systemic inflammatory condition. We found the difference between HOMA of homozygotes GG and G-308A allele carriers. TNF- $\alpha$ may be an important mediator of insulin resistance in obesity through its ability to decrease the tyrosine kinase activity of the insulin receptor interfering with insulin action [18]. We showed the influence of $G-308 \mathrm{~A}$ TNF- $\alpha$ polymorphism on metabolic parameters. We found lower concentrations of HDL cholesterol in boys carrying A allele. We also found the carriers of A alleles presented a stronger tendency for higher values of fasting glucose concentrations, but not for fasting insulin levels. The mechanisms of TNF- $\alpha$ action on metabolic parameters may be explained by impaired glucose uptake into adipocytes by TNF- $\alpha$. TNF- $\alpha$ also inhibits the uptake of FFA. Although the mechanism of FFA uptake is debatable, TNF- $\alpha$ down-regulates the expression of FA translocases in adipose tissue as well as the FA-binding protein FABP4/aP2. TNF- $\alpha$ also inhibits the activity of lipoprotein lipase (LPL) [34]. In our study leptin was not different across genotypes. The regulation of leptin production by TNF- $\alpha$ is unclear. Generally TNF$\alpha$ promotes leptin release from adipocytes [35] and circulating TNF- $\alpha$ levels positively correlate with serum leptin concentrations in obese patients with T2D [36]. In the absence of TNF- $\alpha$, obesity-induced hyperleptinemia is significantly reduced. However, the mechanism by which this is mediated is currently unclear as the transcriptional up-regulation is contextdependent [35]. At present, we can speculate as to how TNF- $\alpha$ might promote obesity. One way could be through interaction with insulin receptor signaling, another way could be through local effects in adipose tissue, for example, by influencing lipolysis or apoptosis in adipocytes. The prevalence of the pediatric metabolic syndrome in children with obesity is growing much more rapidly in developing countries than in industrialized countries [37]. The metabolic syndrome in children phenotype is less well understood than in adults. Abnormalities such as obesity, hypertension and lipid derangements are known to track from childhood to adulthood, and the collected abnormalities may similarly track [38]. The new definition used by the IDF requires the presence of central obesity and two of the four factors. In our study of 124 children, according to a new definition of IDF, 33\% of them presented with full metabolic syndrome, but a comparison of appearance of the metabolic syndrome factors of individuals with the $\mathrm{A}$ alleles and in the group of wild homozygous showed only minor differences. In conclusion, our results suggest that the G-308A mutation of the TNF- $\alpha$ gene, albeit more common in children with obesity is unlikely to play a leading role in the development of obesity and its related metabolic abnormalities, such as insulin resistance, dyslipidemia, and the incidence of MetS in children.

Conflicts of interest: No conflicts of interests were declared by the authors in relation to this article.

\section{REFERENCES}

1. Strauss RS, Pollack HA. Epidemic increase in childhood overweight. JAMA 2002; 86: 2845-8.

2. Dietz WH. Health consequences of obesity in youth: childhood predictors of adult disease. Pediatrics 1998; 101: 518-25.

3. DeFronzo RA, Ferrannini E. Insulin resistance: a multifaceted syndrome responsible for NIDDM, obesity, hypertension, dyslipidemia and atherosclerotic cardiovascular disease. Diabetes Care 1991; 14: 173-94.

4. Ferroni P, Basili S, Falco A, Davi G. Inflammation, insulin resistance, and obesity. Curr Atheroscler Rep 2004; 8: 424-31.

5. Yusuf S, Reddy S, Ounpuu S, Anand S. Global burden of cardiovascular diseases. Part II. Variations in cardiovascular disease by specific ethnic groups and geographic regions and prevention strategies. Circulation 2001; 104: 2855-64.

6. Barsh GS, Faroogi IS, O'Rahilly S. Genetics of bodyweight regulation. Nature 2000; 404: 644-51.

7. Kawakami M, Murase T, Ogawa H, Ishibashi S, Mori N, Takaku F, Shibata S. Human recombinant TNF suppresses lipoprotein lipase activity and stimulates lipolysis in 3T3-L1 cells. J Biochem (Tokyo) 1987; 101: 331-8.

8. Beutler B, Greenwald D, Hulmes JD, Chang M, Pan YC, Mathison J, Ulevith R, Cerami A. Identity of tumour necrosis factor and the macrophage-secreted factor cachectin. Nature 1985; 316: 552-4.

9. Torti FM, Dieckmann B, Beutler B, Cerami A, Ringold GM. A macrophage factor inhibits adipocyte gene expression: an in vitro model of cachexia. Science 1985; 229: 867-9.

10. Brandt E, Schorr U, Kunc I, Kertmen E, Ringel J, Distler A, Sharma AM. Tumor Necrosis Factor-alpha 308 G/A polymorphism in obese Caucasians. Int J Obes Relat Metab Disord 2001; 25: 581-5.

11. Hoffstedt J, Eriksson P, Hellstrom L, Rossner S, Ryden $\mathrm{M}$, Arner P. Excessive fat accumulation is associated with the TNF- $\alpha$ G/A promoter polymorphism in women but not in men. Diabetologia 2000; 43: 117-20.

12. Popko K, Gorska E, Potapinska O, Wasik M, Stoklosa A, Plywaczewski R, Winiarska M, Gorecka D, Sliwinski P, Popko M, Szwed T, Demkow U. Frequency of distribution of inflammatory cytokines IL- 1 , IL- 6 and TNF- $\alpha$ gene polymorphism in patients with obstructive sleep apnea. J Physiol Pharmacol 2008; 59 Suppl 6: 607-14. 
13. Di Rocco P, Manco M, Rosa G, Greco AV, Mingrone G. Lowered tumor necrosis factor receptors, but not increased insulin sensitivity, with infliximab. Obes Res 2004; 12: 734-739.

14. Kubaszek A, Pihlajamaki J, Komarovski V, Lindi V, Lindström J, Eriksson J, Valle TT, Hämäläinen $H$, IlanneParikka P, Keinänen-Kiukaanniemi S, Tuomilehto J, Uusitupa M, Laakso M. Promotor polymorphism of the TNF- $\alpha(G-308 \mathrm{~A})$ and IL $(C-174 \mathrm{G})$ genes predict the conversion from impaired glucose tolerance to type 2 diabetes the Finnish Diabetes Prevention Study. Diabetes 2003; 52: 1872-5.

15. Dalziel B, Gosby AK, Richman TM, Bryson JM, Caterson ID. Association of the TNF- $\alpha 308 \mathrm{G} / \mathrm{A}$ promoter polymorphism with insulin resistance in obesity. Obes Res 2002; 10: 401-5.

16. Day CP, Grove J, Daly AK, Stewart MW, Avery PJ, Walker M. Tumor Necrosis Factor alpha gene promoter polymorphism and decreased insulin resistance. Diabetologia 1998; 41: 430-4.

17. Sookoian SC, Gonzales C, Pirola CJ. Meta-analysis on the G-308A tumor necrosis factor alpha variant and phenotypes associated with the metabolic syndrome. Obes Res 2005; 13: 2122-33.

18. Hotamisligil GS, Peraldi P, Budavari, A, Ellis R, White MF, Spiegelman BM. IRS-1-mediated inhibition of insulin receptor tyrosine kinase activity in TNF- $\alpha$ and obesity-induced insulin resistance. Science 1996; 272: 665-8.

19. Slaughter MH, Lohman TG, Boileau RA, Horswill CA, Stillman RJ, Van Loan MD, Bemben DA. Skinfold eguations for estimation of body fatness in children and youth. Hum Biol 1988; 60: 709-23.

20. Zimmet P, Alberti G, Kaufman F, Tajima N, Silink M, Arslanian S, Wong G, Bennett P, Shaw J, Caprio S. International Diabetes Federation Task Force on Epidemiology and Prevention of Diabetes. The metabolic syndrome in children and adolescents. Lancet 2007; 369: 2059-61.

21. Jellema A, Plat J, Mensink RP. Weight reduction, but not a moderate intake of fish oil, lowers concentrations of inflammatory markers and PAI-1 antigen in obese men during the fasting and postprandial state. Eur J Clin Invest 2004; 34: 766-3.

22. Cawthorn WP, Sethi JK. TNF- $\alpha$ and adipocyte biology. FEBS Lett 2008; 582(1):117-31.

23. Norman RA, Bogardus C, Ravussin E. Linkage between obesity and marker near the tumor necrosis factor-alpha locus in Pima Indians. J Clin Invest 1995; 96: 58-62.

24. Fernandez-Real JM, Gutierrez C, Ricart W, Casamitjana R, Fernandez-Castaner M, Vendrell J, Richart C, Soler J. The TNF- $\alpha$ gene NcoI polymorphism influences the relationship among insulin resistance, percent body fat, and increased serum leptin levels. Diabetes 1997; 46: 1468-71.

25. Romeo S, Sentinelli F, Capici F, Arca M, Berni A, Vecci E, Di Mario U, Baroni MG. The G-308A variant of the Tumor Necrosis Factor- $\alpha$ (TNF- $\alpha$ ) gene is not associated with obesity, insulin resistance and body fat distribution. BMC Med Genet 2001; 2: 10-14.

26. Koch M, Rett K, Volk A, Maerker E, Haist K, Weisser M, Rettig A, Renn W, Häring HU. The tumor necrosis factor alpha $238 \mathrm{G} \rightarrow \mathrm{A}$ and $308 \mathrm{G} \rightarrow \mathrm{A}$ promoter polymorphisms are not associated with insulin sensitivity and insulin secretion in young healthy relatives of type II diabetic patients. Diabetologia 2000; 43: 181-4.
27. Walston J, Seibert M, Yen CJ, Cheskin LJ, Andersen RE. Tumor necrosis factor-alpha 238 and -308 polymorphisms do not associated with traits related to obesity and insulin resistance. Diabetes 1999; 48: 2096-8.

28. Lee SC, Pu YB, Thomas GN, Lee ZS, Tomlinson B, Cockram CS, Critchley JA, Chan JC. Tumor necrosis factor alpha gene $G-308$ A polymorphism in the metabolic syndrome. Metabolism 2000; 49: 1021-4.

29. Srinivasan SR, Myers L, Berenson GS. Predictability of childhood adiposity and insulin for developing insulin resistance syndrome (syndrome $\mathrm{X}$ ) in young adulthood: the Bogalusa Heart Study. Diabetes 2002; 51: 204-9.

30. Cruz ML, Huang T'T, Johnson MS, Gower BA, Goran MI. Insulin sensitivity and blood pressure in black and white children. Hypertension 2002; 40: 18-22.

31. Pausova Z, Deslauriers B, Gaudet D, Tremblay J, Kotchen TA, Larochelle P, Cowley AW, Hamet P. Role of tumor necrosis factor-alpha gene locus in obesity and obesity-associated hypertension in French Canadians. Hypertension 2000; 36: 14-9.

32. Patel JN, Jager A, Schalkwijk C, Corder R, Douthwaite JA, Yudkin JS, Coppack SW, Stehouwer CD. Effects of tumour necrosis factor-alpha in the human forearm: blood flow and endothelin-1 release. Clin Sci (Lond) 2002; 103: 409-15.

33. Klemm P, Warner TD, Hohlfeld T, Corder R, Vane JR. Endothelin-1 mediates ex vivo coronary vasoconstriction caused by exogenous and endogenous cytokines. Proc Natl Acad Sci USA 1995; 92: 2691-5.

34. Memon RA, Feingold KR, Moser AH, Fuller J, Grunfeld C. Regulation of fatty acid transport protein and fatty acid translocase mRNA levels by endotoxin and cytokines. Am J Physiol 1998; 274: E210-17.

35. Kirchgessner TG, Uysal KT, Wiesbrock SM, Marino MW, Hotamisligil GS. Tumor necrosis factor-alpha contributes to obesity-related hyperleptinemia by regulating leptin release from adipocytes. J Clin Invest 1997; 100: 2777-82.

36. Katsuki A, Sumida Y, Murashima S, Murata K, Takarada Y, Ito K, Fujii M, Tsuchihashi K, Goto H, Nakatani K, Yano Y. Serum levels of tumor necrosis factor-alpha are increased in obese patients with noninsulin-dependent diabetes mellitus. J Clin Endocrinol Metab 1998; 83: 85962.

37. Kelishadi R. Childhood overweight, obesity, and the metabolic syndrome in developing countries. Epidemiol Rev 2007; 3: 1-15.

38. Katzmarzyk PT, Perusse L, Malina RM, Bergeron J, Despres JP, Bouchard C. Stability of indicators of the metabolic syndrome from childhood and adolescence to young adulthood: The Quebec Family Study. J Clin Epidemiol 2001; 54: 190-5.

Address for correspondence:

Beata Pyrzak

Department of Pediatrics and Endocrinology

Medical University of Warsaw

24, Marszalkowska St.

00-576 Warsaw

Poland

Phone: +48 225227435

Fax: +48 226214155

E-mail: beata.pyrzak@wum.edu.pl 